\title{
Assessment on Carbon Stock of Natural and Plantation Forest in Setema District, Jimma Zone, South West Ethiopia
}

\author{
Ajibu Awol Gobena \\ Department of Forestry, College of Agriculture and Natural resource, Bonga University, Bonga, Ethiopia
}

\begin{abstract}
A Carbon Stock of Natural and Plantation Forest in Setema District, Jimma, South West Ethiopia was conducted. Carbon (C) densities of the biomass and soil $(0-40 \mathrm{~cm})$ in the natural forest and plantations of E.globulus and $\mathrm{C}$. lusitanica in the Setema forest were determined and compared. In the stratum or forest stand, sample plots of 20 $\mathrm{m} \times 20 \mathrm{~m}$,(square) were randomly laid to measure the biomass of woody plants, a total of 90 (30 in each stratum) sample plots were taken for $\mathrm{C}$ stock inventory. Biomass $\mathrm{C}$ densities were estimated from total tree height, breast height diameter and wood density using allometric functions developed for tropical species and an assumed $\mathrm{C}$ content of $50 \%$. Belowground biomass $\mathrm{C}$ densities were estimated using root: shoot biomass ratios. Soil organic C (SOC) densities were calculated from measured organic carbon contents (0-20 and 20-40 cm layers) and modeled bulk density values. Mean total biomass $\mathrm{C}$ densities for natural forest were greater than those of the plantations, and mean total SOC densities for plantations were greater than those of the natural forest, and the difference was significant $(\mathrm{p}<0.05)$ in the cases of plantation and natural forest, but not significant in SOC in the case of E. globulus plantation species. Natural forests can store more total $\mathrm{C}$ stocks than plantations of exotic species, but the difference between natural forest and plantation of exotic was depended on plantation species. Therefore, species selection is vital when establishing tree plantations with the aim of the restoration of degraded soils and biomass carbon stocks. Conservation of the natural forest will have an imperative implication to the total $\mathrm{C}$ density and ensuring its viability.
\end{abstract}

Keywords: biomass; carbon stocks; C. lusitanica; E. globulus; natural forest; soil carbon stocks

DOI: $10.7176 / \mathrm{JETP} / 12-1-01$

Publication date: January $31^{\text {st }} 2022$

\section{INTRODUCTION}

\subsection{Background}

Forest ecosystems are the major terrestrial ecosystem comprising 4.1 billion ha (Brown et al., 2002) and are significantly important in reducing the increasing rate of carbon dioxide $\left(\mathrm{CO}_{2}\right)$ build-up in the atmosphere responsible for climate change (Streck and Scholz, 2006). Forests are playing an important and uncountable role in the terrestrial carbon cycle. Forest ecosystems can sequestrate and store carbon through the photosynthetic process of absorption atmospheric $\mathrm{CO}_{2}$ and subsequent storage in the form of tree biomass (stem trunks, branches, foliage, roots, etc.), (Malhi et al., 2002; Houghton, 2005) and in the form of litter, woody debris, soil organic matter, forest products (Malhi et al., 2002), and hummus or organic carbon in the soil (Houghton, 2005).

Forest vegetation and soils constitute a major terrestrial carbon pool with the potential to absorb, sequestrate, or uptake and store carbon dioxide $\left(\mathrm{CO}_{2}\right)$ from the atmosphere. The $\mathrm{CO}_{2}$ source and sink dynamics as trees grow, die, vegetation type, topographic dynamics, temperature variations, and decay are subject to disturbance and forest management. Evidence of climate change linked to activities of the increase in greenhouse gas (GHG) concentrations is well-documented in international studies (IPCC, 2001; 2007). The recognized and importance's of forests in mitigating climate change has led countries to study their forest carbon budgets and initiate the assessment of enhancing and maintaining carbon sequestration of their forest resources.

The total global potential for afforestation enhancing rehabilitation of degraded natural forest and reforestation activities for the period 1995-2050 is estimated to be between 1.1 and $1.6 \mathrm{Pg} \mathrm{C}$ ( $1 \mathrm{Pg}=\mathrm{Peta}$ gram, $10^{15}$ gram ) per year, of which 70\%, could occur in the tropics (IPCC, 2000). The vegetation of tropical forests is large and play globally significant role in the storage of $\mathrm{C}$ stocks per unit area than any other land cover types (Hairiah et al., 2011). Afforestation, reforestation of non-forest land and rehabilitation of degraded forest because and management of forest plantations can enhance SOC stock through C sequestration (Lal, 2005).

Land use and plant species also have a significant influence on SOC estimations. In the tropics, deforestation, and changes in land use land covers are significantly impacting the global carbon cycle by increasing the rate of carbon emissions (Silver et al., 2000). Converting of the forest into agricultural ecosystems negatively affects SOC concentration and stock by 20-50\% (Solomon et al., 2002; Lal, 2005; Lemenih and Itanna, 2004). In tropical forests, which serve as powerful carbon sinks, deforestation accounts for $20 \%$ of total anthropogenic activities $\mathrm{CO}_{2}$ emissions into the atmosphere (Baccini et al., 2008).

Establishment of exotic species, the plantation can have several advantages and roles. The relatively fast growth rate of exotic species provides wood to be used for various purposes to human. In further, recent studies on tropical tree plantations indicate that exotic species may facilitate the regeneration of native species under the 
canopy and catalyzes the subsequent succession processes (Yirdaw, 2002). Trees have beneficial effects that are associated with improved soil structure through root action and inputs of organic matter (Olsson, 2001). They can increase the availability of nutrients through enhanced nutrient cycling and can also improve degraded soils by improving soil nutrient status through increased inputs and reduced outputs, (Jobbágy and Jackson, 2001).

In order to minimize deforestation, the Setema forest has been managed under Oromia Forest and Wildlife Enterprise (OFWE) and receives more attention due to its potential as a carbon sink and storage. Alternative strategies to reduce the pressure on the native forest by alleviating the fuel-wood shortage include fast-growing tree and shrub plantations around homesteads, the establishment of clear farm boundaries and wood lots in nearby rural communities (OFWE Office, 2018). At the same time, carbon assessment above ground and below ground carbon stocks of different selected plantation species and natural forest is generating vital information regarding the importance of the forest for carbon exchange and climate change mitigation at local, regional and international levels.

Climate change, caused by global warming, is a phenomenon partly resulting from an abundance of carbon dioxide in the atmosphere. It is the most pressing environmental problem in the world today. Forests provide materials particularly the moist southwestern natural forests support the production of important spices such as ginger (Zingiber officinale), cinnamon (Cinnamomum zeylanicum) and cardamom (Elettaria cardamomum) in addition to climate change mitigation (Girma, 1998). Forests are also important in watershed management, soil protection and biodiversity conservation. Particularly the mountain forests in Ethiopia are situated for capturing and storing rainfall and moisture, maintaining water quality, regulating river flow and reducing soil erosion (FAO, 2003). The importance of Ethiopian forests in the conservation of forest genetic resources has also been rated as one of the highest in Africa (De Vletter, 1991).

Plantation systems as land use can reduce the atmospheric concentration of carbon dioxide. Carbon sequestration through forestry plantations has a huge potential to improve global environmental problems such as atmospheric accumulation of carbon dioxide and related climate change. In Ethiopia Eucalyptus globulus, and Cupressus lusitanica, and are among common exotic plantation species (Gebrekidan Teklu, 2003). They grow fast, a characteristic that makes them remove more carbon dioxide $\left(\mathrm{CO}_{2}\right)$ from the atmosphere than they would release. Meta-analysis studies have shown that replacing native forest with agricultural crops or plantations (at least when less than 40 years of age) generally reduces soil carbon stocks (Guo and Gifford, 2002; Liao et al., 2010) and conversely, the establishment of forest on agricultural land use generally increases soil carbon stocks (Lemma et al., 2006). However, according to Glenday (2006) that tree biomass and soil $\mathrm{C}$ densities in the natural forest was not consistently greater than in plantations of exotics, but depending on plantation age and species diversities.

The Setema natural forest is one of the remaining forests in South Western parts of Ethiopia. More than 300 hectors of natural forest was replaced by exotic species plantation. However, the area of natural forest has declined, and become fragmented and degraded as a result of deforestation and planting exotic tree species. While the tree biodiversity of the natural forests has existed, there is no information known about their biomass and soil $\mathrm{C}$ densities, how they compare with those of plantations and, level of impact within natural forest and different plantation species concerning the importance of the forest for carbon stocks and climate change mitigation and ensure the sustainability of the forest of Setema district.

This study therefore aimed to generate data on the comparative assessment of natural and different tree plantation species of forest carbon stocks in setema district so the major aim of this study is to assess carbon stocks of plantations forest and compare it to its adjacent natural forest in Setema woreda South West Ethiopia, To assess biomass carbon stocks of selected tree plantations and compare it to its adjacent natural forest. To assess soil organic carbon stock of land under selected tree plantations and compare it to its adjacent natural forest. To assess ecosystem carbon stocks of selected tree plantations and compare it to its adjacent natural forest.

\section{MATERIALS AND METHODS}

\subsection{Study area description}

The study was conducted in Setema district of Oromia region in the southwestern Ethiopia. Geographically, it is located between $8^{\circ} 2^{\prime}$ to $8^{\circ} 4^{\prime}$ North latitude and $30^{\circ} 20^{\prime}$ to $30^{\circ} 28^{\prime}$ East longitude. The study area is located at about 450 kilometers away from Addis Ababa, the capital city of Ethiopia and $100 \mathrm{~km}$ in North West of Jimma town. Setema is bordered on the south by Gera, on the west by Sigmo, on the north by the Illubabor Zone, and on the Southeast by Gomma. The administrative center of the woreda is Gatira. The highest points are in the Damu Siga mountain range. Perennial rivers include the Onja, Salako, Gidache and Gebba. A survey of the land in this woreda shows that from 153,273 hectares total woreda area, $27.2 \%$ is arable or cultivable $(20.8 \%$ was under annual crops), $13.1 \%$ pasture, $55.1 \%$ forest, and the remaining $4.6 \%$ are considered degraded, built up or otherwise unusable. The majority of the Sigmo-Geba State Forest, about 100 square kilometers (39 sq mi) in size, is located in Setema. Teff, Corn, and sheep are important cash crops. Although coffee is also an important cash crop in this woreda, less than 20 square kilometers $(7.7 \mathrm{sq} \mathrm{mi}$ ) are planted with this coffee production. The altitude of this woreda ranges from 1,500 to 3,000 meters above sea level. 


\subsubsection{Vegetation}

The forest is classified under moist Afromontane forest consisting high diversity of endemic tree species and a variety of wildlife. Setema forest covers about 16,300 hectares (ha) of land comprising of species-rich natural and various tree plantations including E. globulus and C. lusitanica and other exotic species. In the Setema woreda Oromia Forestry and Wildlife Enterprise (OFWE) planted different exotic species including E. globulus ( $>250$ ha) and $C$. lusitanica ( $>300 \mathrm{ha}$ ) on the most of natural forest boundaries. These exotic species are mainly planted on land that had been cleared of natural forest. The purposes of the plantations are for timber production, to serve as buffers to protect the remaining natural forest, and to mitigation against soil erosion (OFWE, 2018). The plantations have not been utilized by local communities. The location of the area is shown in Fig. 1.

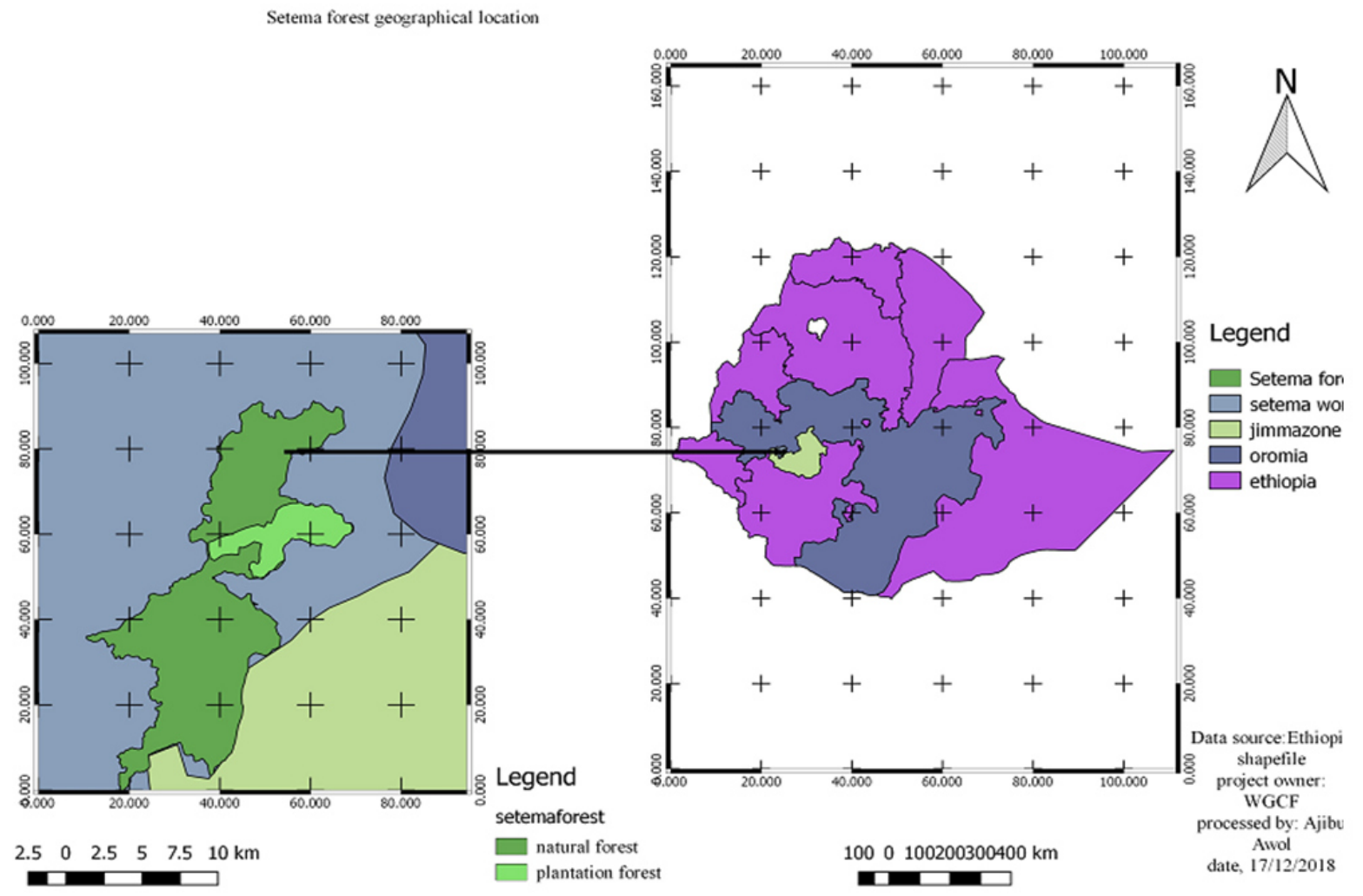

Figure 1: map of study area, it is located between $8^{\circ} 2^{\prime}$ to $8^{\circ} 4^{\prime} \mathrm{N}$ and $30^{\circ} 20^{\prime}$ to $30^{\circ} 28^{\prime} \mathrm{E}$.

\subsubsection{Climate conditions}

The mean annual rainfall in the study area is $1665 \mathrm{~mm} /$ year. Western and southwestern parts of the country experience a unimodal rainfall pattern. October to January (Birra) denotes the time when the long rainfall season comes to an end to be followed by a medium to the short dry season during the same period. February to May (Bona) is the start of the long rainy season. Over the western parts of the country in the region also the rainy season starts during March/April. June to September (Main season) is a long and heavy summer rain, normally called the big rain or Gannaa, which falls from June to September. The study area annual average maximum temperature is $27.9^{\circ} \mathrm{c}$ and the minimum temperature is $11.9^{\circ} \mathrm{c}$. Change in time/quantity of seasonal and annual rainfall is an important factor in the agriculture activities of the study areas. In general $80 \%$ of the woreda is semi-arid (wayina dega) and $20 \%$ is high land (dega) there is no desert (kolla) in the area.

\subsubsection{Soil}

The soil type of the study area is dominated and characterized as black to red soils; those are sandy soil, loamy soil, and clay soil.

\subsubsection{Demographics}

The 2018 woreda health office reported total populations for this woreda of 142,635, of whom 7763 are urban dwellers and 134872 are woreda rural population 67909 are children less than 15 ages. The majority of the inhabitants are Muslim religion followers, with $96.91 \%$ of the population reporting they observed this belief, while $2.67 \%$ of the population said they practiced Ethiopian Orthodox Christianity. The three largest ethnic groups reported in Setema were the Oromo (96.48\%), the Amhara (2.22\%), and the Tigre (1.0\%); all other ethnic groups made up $0.3 \%$ of the population. Afaan Oromo was spoken as a first language by $97.17 \%, 1.75 \%$ spoke Amharic and $0.97 \%$ spoke Tigringa; the remaining $0.11 \%$ spoke all other primary languages reported.

\subsubsection{Economic activities}

Agriculture is the main economic activities and is dominated by small-scale and mixed crop and livestock farmers. 
More than $90 \%$ of woreda population are depends on agricultural activities. Crop production is mainly rainfed. Coffee plays a major role in income generation in the areas. Maize, Teff (Eragrostis teff) and sorghum (Sorghum bicolor) are the major crops grown in the area. Pulses crops, such as, beans and pea are grown to a lesser extent in the area (Dechassa, 2000).

\subsection{Conceptual frame work}

The conceptual model that was used in this study shows how to determine the biomass and soil organic carbon stock in the study sites, to achieve the idea of study objectives.

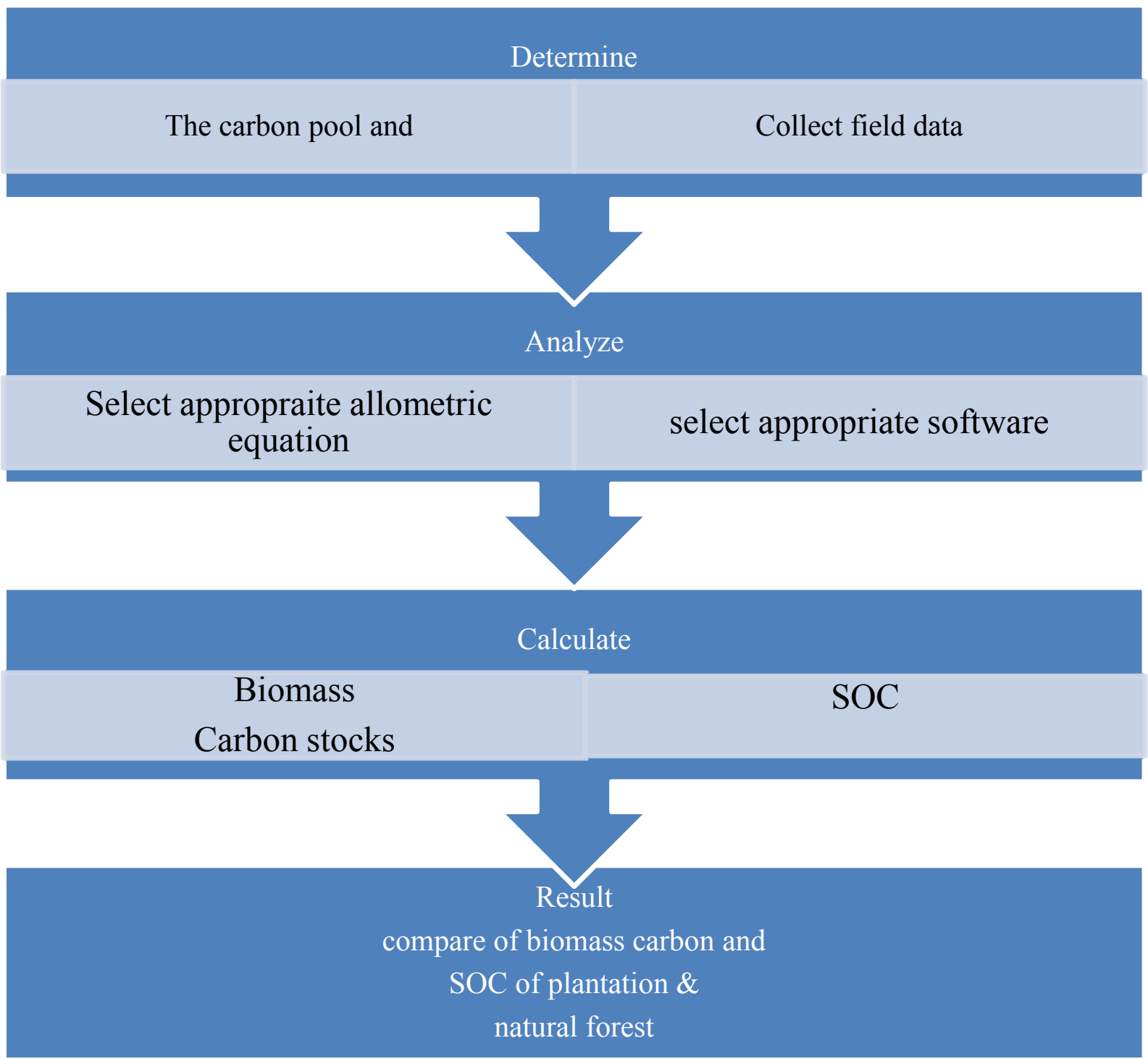

Figure 2: conceptual frame work

This conceptual model that was used to shows how determines the biomass and soil organic carbon stock and ecosystem carbon in the site, to achieve the idea of study objectives.

\subsection{Delineation of forest boundary}

The study forest area boundaries were delineated to facilitate measurement and accounting of forest carbon stocks (Bhishma et al., 2010), by using QGIS. Global positioning system (GPS) was used for navigation of the sample point of the study area by taking the coordinates of each turning sample point.

\subsection{Stratification of the study area}

Stratification helps in the forest to get accurate data, to save time and energy in addition, to maintain the homogeneity of the area (Kassahun, 2015). Forest and species types are the major parameters to classify the study area. The strata are defined at each forest and species types, stratified into the natural forest and plantation forest, 
then similar age plantation which were previously natural forest were stratified based on species into E. globulus and C. lusitania plantation.

\subsection{Sampling design and techniques}

Stratified simple random sampling method was used to take samples. Sample points distributed randomly by QGIS. In the stratum or forest stand, sample plots of $20 \mathrm{~m}$ x $20 \mathrm{~m}$, were randomly laid to measure the biomass of woody plants, a total of 90 sample plots were taken for C stock inventory. Sample plots in the same stratum, namely E. globulus, C. lusitanica, and natural forest were computed to give average biomass and C stock for each stand type and other square plots of $1 \mathrm{~m}$ x $1 \mathrm{~m}$ square plots were set up within $20 \mathrm{~m}$ x $20 \mathrm{~m}$ sample plots for soil sampling. The soil samples were taken for the bulk density and soil carbon stock analysis. Soil samples were collected from quadrants $\left(1 \mathrm{~m}^{2}\right)$ allocated in the four directions (at four corners of square sample plots) and one in the center as shown in figure 3 .

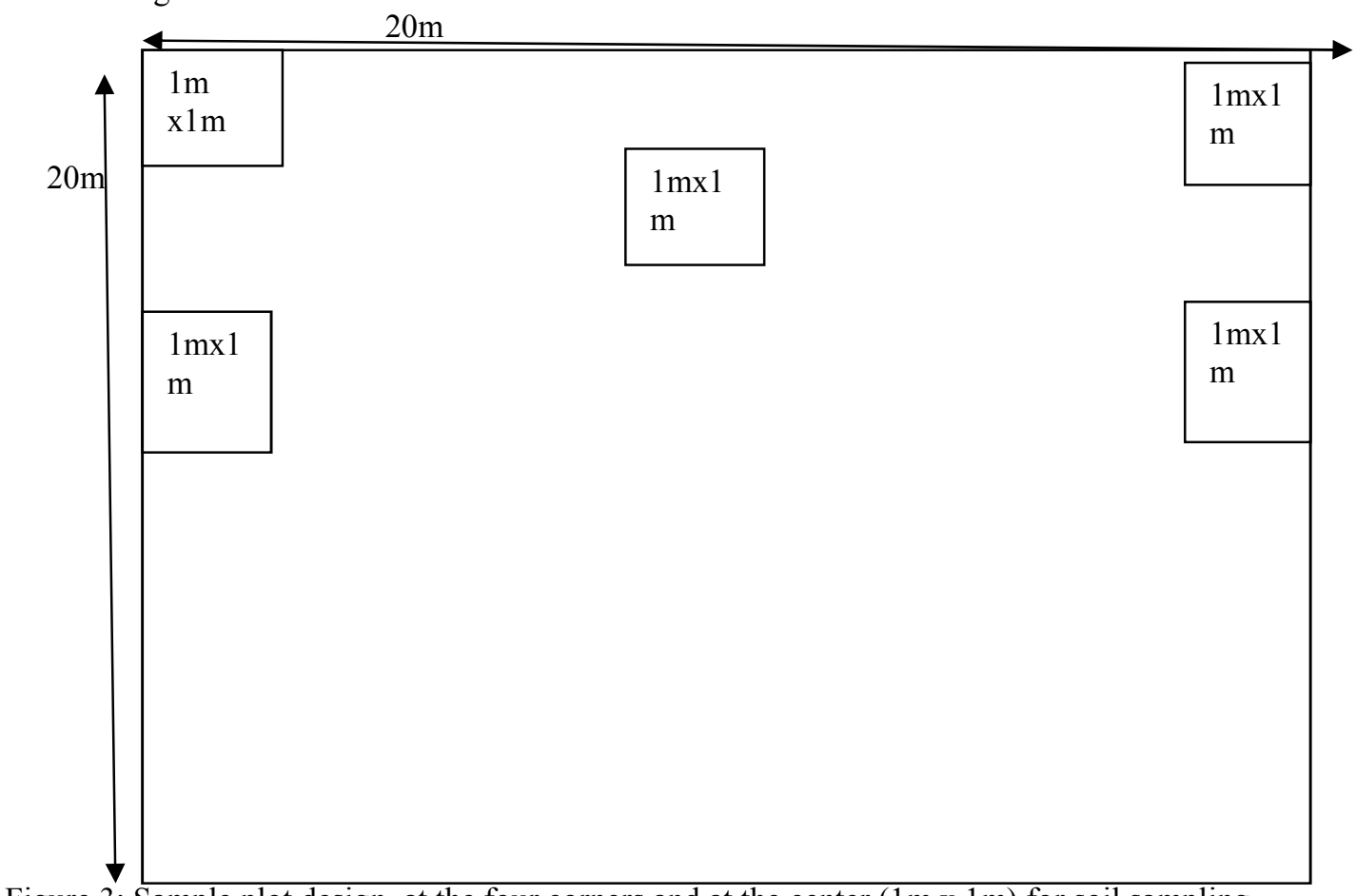

Figure 3: Sample plot design, at the four corners and at the center (1m x 1m) for soil sampling.

\subsection{Sample size (sample plot numbers)}

To estimate forest biomass and carbon stock potential that is statistically and practically efficient, enough sampling units should be measured to obtain the desired standard of precision no more, no less (Thomas et al., 2015). The number of sample plots for biomass estimation (in other terms, the sample size) is generally selected empirically, based on rules established by experience. A general principle is that, for any given precision, the more variable the material, the larger the sample size: smaller sample sizes are required for a plantation. When the cost of selecting an item is equal for each stratum, there is no difference in within stratum variances, and the purpose of sampling happens to be to estimate the population value of some characteristics. In case, the purpose happens to be to compare the differences among strata, then equal samples election from each stratum would be more efficient even if strata differ in sizes (Picard et al., 2012). Thirty (30) sample plots for single, homogeneous plantation site was recommended by Picard et al., (2012). Based on this experience a total of 90 samples (30 samples for each stratum) were taken for estimation of natural forest and selected tree plantation biomass carbon stock. Vegetation sample points were distributed as shown on the following figure 4. 


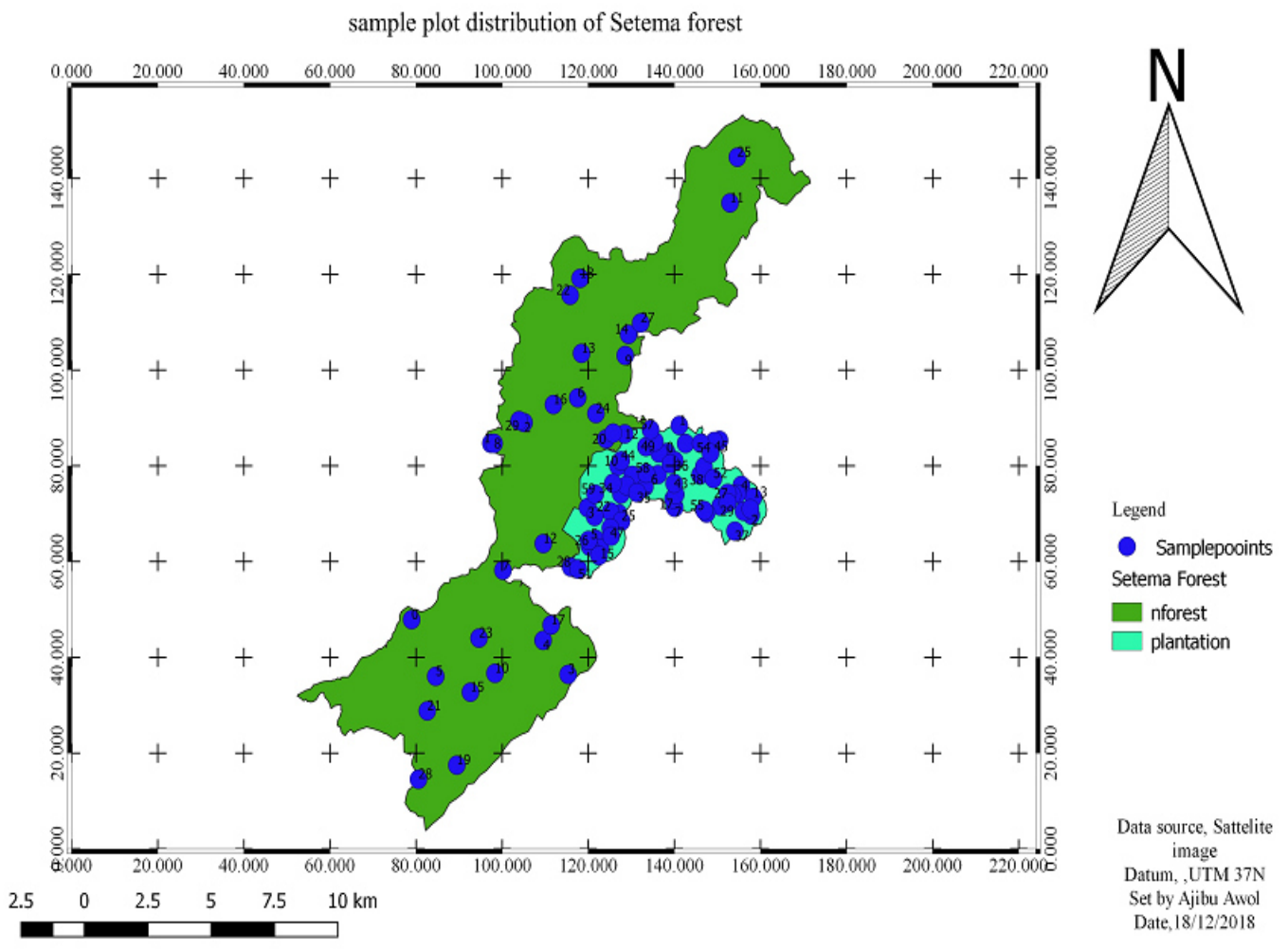

Figure 4: map of Setema forest area and sample plot distribution

\subsection{Vegetation survey}

Biomass data were collected at two different selected tree plantation species and adjacent natural forest. At each species selected of tree plantation and natural forest, a number of sample plots were distributed to the forest areas. A square sample plots were established randomly in all study sites. Diameter at breast height (DBH) of each tree $(\geq 5 \mathrm{~cm}$ ) within a $20 \mathrm{~m} \times 20 \mathrm{~m}$ sample plot was measured by using the caliper and height of each tree were measured by using a hypsometer. Trees with multiple stems, ambiguous and forked above DBH are treated as a single tree. A canker, gall or branched trees at DBH have measured of the smallest point below it where the stem assumes near cylindrical shape. Trees with multiple stems or fork below DBH are treated as a single individual stem (Pearson et al., 2005). To estimate the above-ground biomass of all trees within the selected site having DBH $>5$ $\mathrm{cm}$ were recorded. These inventory data were used to calculate stocking $\left(\right.$ stems ha $\left.\mathrm{h}^{-1}\right)$, basal area $\left(\mathrm{m}^{2} \mathrm{ha}^{-1}\right)$.

\subsection{Soil sampling}

Soil samples were collected at two depths $(0-20 \mathrm{~cm}$ and $20-40 \mathrm{~cm})$ from ten $(10)$ plots in each stratum. From each plot, five samples were taken from the topsoil $(0-20 \mathrm{~cm})$ and five from the $20-40 \mathrm{~cm}$ depth. Within $1 \mathrm{x} 1 \mathrm{~m}$ quadrant five soil samples were taken by digging a pit to a depth of $40 \mathrm{~cm}$, and the five soil samples were composited according to their layer (Roshetko et al., 2002; Takimoto et al., 2008). The soil sample was mixed homogeneously, and $100 \mathrm{~g}$ sub-sample was taken from each sample for laboratory analysis. In addition, from the same quadrants, soil samples from two $(0-20$ and $20-40 \mathrm{~cm})$ depths for soil bulk density determination were collected from the surface soil using $20 \mathrm{~cm}$ length and $5 \mathrm{~cm}$ diameter core sampler carefully driven into the soil to avoid compaction (Roshetko et al., 2002).

\subsection{Data analysis}

\subsubsection{Carbon stock estimation}

\subsubsection{Aboveground biomass of natural forest}

As usual methods for determining of the aboveground biomass (AGB) of forests are the combination of forest inventories with allometric tree biomass regression models (Houghton et al., 2001; Brown, 2002; Houghton, 2005). This estimation of AGB in the forest ecosystem is based on plot inventories that involve the following three steps (Houghton et al., 2001; Chave et al., 2005).

1. Selection and application appropriate allometric biomass equation for the estimation of individual tree biomass 
based on the forest type.

2. Summation of all individual tree AGB to estimate plot AGB, and

3. Calculation of an across-plot average to hectare bases.

To the estimate below and aboveground biomass, all tree/shrub species with DBH $\geq 5 \mathrm{~cm}$ were measured in each sample point using Caliper and Diameter Tape. In addition, the total tree heights (to the top of the crown) were measured using Hypsometer (Brown, 2002; Pearson et al, 2007). Tree diameter was measured at breast height $(\mathrm{DBH})$ of individual trees standing at $1.3 \mathrm{~m}$ which are greater or equal to $5 \mathrm{~cm} \mathrm{DBH}$ in each square sample plots of $400 \mathrm{~m}^{2}$ in area. Tree (DBH) was measured by diameter tape and caliper. Diameter tape was used to measure tree diameter which is very big and not suitable to measure by using a caliper. Each tree was recorded individually with its species, in the plot, local names of trees were records and later scientific names were identified from "Useful Trees and Shrubs for Ethiopia" (Bekele, 2007). In this study, the allometric equation given by Chave et al., (2014) was used to estimate AGB. The equation was used since the general criteria described by the author are similar to the study area. Ethiopia also used the same equation to submit its FREL to the UNFCCC (FERL, 2016; 2017). The inclusion of country-specific wood density in the equation significantly improves biomass estimation (Chave et al., 2014). For this reason, the following parameters are needed to express aboveground biomass in carbon stock: diameter at breast height $(\mathrm{DBH})$, tree height, a wood density factor. While $\mathrm{DBH}$ and height parameters are directly measured in the field, the basic wood density of species was obtained from other studies and databases. Wood basic density of species was used following Ethiopian Forest level submission to UNFCCC (RREL, 2016; 2017).

$\mathrm{AGB}=0.0673 *\left(\rho^{*}(\mathrm{DBH})^{2} * \mathrm{H}\right)^{\wedge} 0.976$ equation (1)

Where,

$\mathrm{AGB}=$ above ground biomass (in kg dry matter)

$\rho=$ wood density $(\mathrm{g} / \mathrm{cm} 3)$

$\mathrm{DBH}=$ diameter at breast height (in $\mathrm{cm})$,

$\mathrm{H}=$ total height of the tree (in $\mathrm{m}$ ).

Aboveground carbon stock of each tree biomass is converted to carbon stock based on the equation below (Brown, 2002)

$\mathrm{AGCS}=\mathrm{AGB} * 0.5$ equation (2)

Where,

AGCS $=$ Above Ground Carbon Stock,

AGB $=$ Above Ground Biomass $(\mathrm{kg} /$ tree $)$

\subsubsection{E. globulus biomass}

Species specific allometric models developed For E. globulus of Ethiopia which directly determined on the biomass measurements (Tesfaye Debela , 2017) was used to estimate above ground biomass of E. globulus.

$\mathrm{AGB}=0.479 *(\mathrm{DBH})^{2.2578} *(\mathrm{H})-0.374$

\subsubsection{C. lusitanica biomass}

Five linear and non-linear biomass and carbon models of $C$. lusitanica were compared and evaluated for estimation of the overall aboveground carbon, carbon by age groups, and carbon by diameter at breast height (DBH) classes using performance indicator statistics (Berhe et al., 2013). Among the models compared, a carbon model described by $Y=b_{0} D^{2} H+\epsilon(p$-value $<0.001)$, where $D=\mathrm{DBH}$ (in cm), $H=$ total height of the tree (in $\left.\mathrm{m}\right), \epsilon=$ error, and $b_{0}\left(b_{0}=0.0319\right)$ is a parameter was found to be the best model for estimation of carbon sequestered in $C$. lusitanica plantation stands of the study area (Berhe et al., 2013). This equation was used to calculate above ground biomass of C. lusitanica.

$\mathrm{AGB}=0.0319 * \mathrm{DBH}^{2} * \mathrm{H}+\mathrm{E}$. .equation (4)

The corresponding carbon content in biomass was estimated assuming $50 \%$ of carbon in the biomass as per IPCC (2003).

\subsubsection{Belowground biomass}

Belowground biomass (BGB), commonly called as root biomass estimation is not easy as AGB calculation, BGB estimation is much more difficult and time-consuming than estimating aboveground biomass (Geider et al., 2001). Roots contribute an important role in the carbon cycle as they transfer considerable amounts of carbon to the ground, where it might be stored for a relatively long period of time. The plant uses part of the carbon in the roots to increase the total tree biomass through photosynthesis, although, carbon is also lost through respiration, and decomposition of the roots. Some roots can penetrate to great depths, but the greatest proportion of the total root mass is within the first $30 \mathrm{~cm}$ of the soil surface. Carbon loss or accumulation and storage in the ground are intense in the top layer of soil profiles $(0-30 \mathrm{~cm})$. Sampling should concentrate on this section of the soil depth (Kassahun et al., 2015). The belowground biomass (BGB) was calculated by multiplying above-ground biomass taking 0.26 as the root to shoot ratio (Ravindranath et al., 2008)

Belowground biomass $\left(\right.$ tha $\left.^{-1}\right)=0.26 \times$ above-ground biomass $\left(\right.$ tha $\left.^{-1}\right)$. equation (5)

Finally, the carbon content in the belowground biomass was estimated by multiplying of BGB by 0.5 IPCC (2003). 


\subsubsection{Estimation of soil organic carbon}

Soil samples for the determination of soil carbon were collected from a sample quadrates laid for soil sampling mean that from four directions and at the center of each sample points to a depth of $40 \mathrm{~cm}$ within each quadrate by digging a pit to a depth of $40 \mathrm{~cm}$, and the five soil samples of each layer was composited (Roshetko et al, 2002; Takimoto et al., 2008). Five equal weights of soil samples from each layer were taken and mixed homogeneously while a $100 \mathrm{~g}$ composite sample was taken from each sample quadrate for determination of organic carbon in the laboratory using Walkley and Black, (1934) method. The soil samples were air-dried, well mixed and sieved through a $2 \mathrm{~mm}$ mesh size sieve for soil carbon analysis following the right technique (Walkley and Black, 1934). In addition, from the same quadrats, soil samples for soil bulk density determination were collected from the surface soil (from 0-20 cm and 20-40 cm depths) using $20 \mathrm{~cm}$ length and $5 \mathrm{~cm}$ diameter core sampler carefully driven into the soil to avoid compaction (Roshetko et al., 2002). The carbon stock density of soil organic was calculated as recommended by (Pearson et al., 2005) from the volume and bulk density of the soil.

$V=h X \pi r^{2}$ equation (6)

Where,

$\mathrm{V}=$ is a volume of the soil in the core sampler augur in $\mathrm{cm} 3$,

$\mathrm{h}=$ is the height of core sampler augur in $\mathrm{cm}$, and

$\mathrm{r}=\mathrm{is}$ the radius of core sampler augur in $\mathrm{cm}$.

Moreover, the bulk density of a soil sample was calculated as follows (pearson et al., 2005):

$B D=\frac{\mathrm{Wa}, \mathrm{dr} y}{\mathrm{~V}}$ equation (7)

Where,

$\mathrm{BD}$ is the bulk density of the soil sample,

Wav, dry is an average oven dry weight of soil sample

$\mathrm{V}$ is a volume of the soil sample in the core sampler in $\mathrm{cm}^{3}$. Then, the soil organic carbon stock pool was calculated using the formula (pearson et al., 2005)

$S O C=B D * d * \% C$. equation (8)

Where,

$\mathrm{SOC}=$ soil organic carbon stock per unit area $(\mathrm{t} / \mathrm{ha})$,

$\mathrm{BD}=$ soil bulk density $(\mathrm{g} / \mathrm{cm} 3)$,

$\mathrm{D}=$ the total depth at which the sample was taken $(0-20 \mathrm{~cm}$ and $21-40 \mathrm{~cm})$, and

$\% \mathrm{C}=$ Carbon concentration $(\%)$ determined in the laboratory.

\subsubsection{Estimation of total carbon stock of the area}

Total carbon stock of the area was calculated by summing the carbon stocks densities of the individual carbon pools of the stratum. In this study, the total carbon stocks of stratum were determined by nondestructive methods which include, field survey, laboratory analysis, and allometric equations. In Setema forest dead wood and litter carbon pools are not included, because the forest area is near to village those carbon pools are intensively collected for fuel-wood purpose. Dead and broken pones are usually withdrawn from plantation stands after several years (Yamaguchi et al., 1963). Saplings which are $<5 \mathrm{~cm}$ DBH also excluded, since there is no regeneration in the plantation forest. Measuring might not be required if the understory is dominated by herbaceous material as this likely would account for negligible changes over the duration of the activity (less than 3 percent) (Pearson and Brown et al., 2007). In addition, it is recommended that any individual carbon pool of the given formula can be ignored if it does not contribute significantly to the total carbon stock (Bishma, 2010). Carbon stock density of a study area:

$\mathrm{C}$ stock $=\mathrm{CAGB}+\mathrm{CBGB}+\mathrm{SOC}$. equation (9)

Where:

$\mathrm{C}$ stock $=$ Carbon stock density for all pools $\left(\right.$ ton $\left.\mathrm{ha}^{-1}\right)$

$\mathrm{CAGB}=$ Carbon in above -ground biomass $\left(\mathrm{t} \mathrm{C} \mathrm{ha-}^{-1}\right)$

$\mathrm{CBGB}=$ Carbon in below-ground biomass $\left(\mathrm{t} \mathrm{C} \mathrm{ha}^{-1}\right)$

$\mathrm{SOC}=$ Soil Organic Carbon

\subsection{Statistical analyses}

Descriptive statistics were calculated to describe the plot biomass and soil C stocks by forest and species type, and forest area. Differences in biomass and soil $\mathrm{C}$ stocks between species and forest types across forest areas were determined using a one-way analysis of variance (ANOVA). The difference between biomass C and SOC densities and its significant effect within each selected plantation species and the related natural forest was tested by using the one way ANOVA. Relations plantation species and the related natural forest were calculated to describe the dependence of $\mathrm{C}$ densities on species and forest types. The statistical analyses were performed using MINITAB version 17. 


\section{RESULT}

\subsection{Stand characteristics}

The range in characteristics of the natural forests and plantations of exotic species are different as shown in Table 1. Those having the largest diameter trees and stand basal area were associated with the natural forest. The natural forest stem densities in Setema were considerably higher than in the plantation forest types. Stem densities were also compared in terms of the plantations of two different species that are E. globulus and C. lusitanica. There was a higher difference in the mean diameter of the trees in the natural forest among forest types.

Table 1: Stand of study plot (stand by forest type) for different forest types in Setema forest.

\begin{tabular}{lllll}
\hline Forest type & Characteristics & Mean & Min & Max \\
\hline Natural forest & DBH(cm) & 28.41 & 5 & 143 \\
& BA(m ${ }^{2} /$ ha $)$ & 37.36 & 13.30 & 44.84 \\
& Stem density(\#/ha) & 587 & 175 & 1025 \\
& & & 55 \\
E. globulus & $\mathrm{DBH}(\mathrm{cm})$ & 25.54 & 5 & 38.23 \\
& $\mathrm{BA}\left(\mathrm{m}^{2} / \mathrm{ha}\right)$ & 36.32 & 28 & 600 \\
Stem density(\#/ha) & 380 & 150 & 63 \\
& & & 5 & 43.59 \\
& $\mathrm{DBH}(\mathrm{cm})$ & 19.45 & 23.74 & 750 \\
\hline
\end{tabular}

$\mathrm{dbh}=$ diameter at breast height; $\mathrm{BA}=$ basal area.

\subsection{Aboveground biomass carbon}

The aboveground biomass carbon was found to be significantly higher in natural forest $(210.8 \mathrm{C} \mathrm{t} / \mathrm{ha})$ followed by E. globulus plantation $(133.7 \mathrm{C} \mathrm{t} / \mathrm{ha})$ and C. lusitanica plantation $(99.8 \mathrm{C} \mathrm{t} / \mathrm{ha})$. The difference was significant at $(\mathrm{p}=0.000$ and $\mathrm{F}=24.91)$ only in the case of the natural forest and plantations, but not significant between plantation species. Larger biomass carbon in the natural forest might be attributed to DBH, species diversity and allometric equation used.

Table 2: Aboveground carbon content of different forest types in $\mathrm{t} /$ ha in Setema, forest Southwestern Ethiopia

\begin{tabular}{lccc}
\hline Forest categories & Mean & St Dev & $95 \%$ CI \\
\hline Natural Forest & 210.8 & 89.1 & $(188.0,233.5)$ \\
E. globulus & 133.7 & 55.6 & $(111.0,156.4)$ \\
C. lusitanica & 99.8 & 27.41 & $(76.54,122.01)$ \\
\hline p-value & & & \\
\hline
\end{tabular}

\subsection{Belowground biomass carbon}

According to this study, there was significant difference in belowground carbon content of different forest types (at $\mathrm{p}=0.000$ and $\mathrm{F}=22.93$ ) as indicated (Table 3). Natural forest and E. globulus sequestered higher and comparable belowground carbon (53.50 and $34.76 \mathrm{t} / \mathrm{ha}$ ) respectively. The belowground carbon content of $C$. lusitanica $(25.81 \mathrm{t} / \mathrm{ha})$ was lower than that of others.

Table 3: Belowground biomass carbon stock of different forest types in $\mathrm{t} / \mathrm{ha}$ in Setema forest Southwestern Ethiopia.

\begin{tabular}{|c|c|c|c|}
\hline Forest categories & Mean & St Dev & $95 \% \mathrm{CI}$ \\
\hline Natural Forest & 53.50 & 22.88 & $(47.63,59.36)$ \\
\hline E. globulus & 34.76 & 14.45 & $(28.90,40.62)$ \\
\hline C. lusitanica & 25.81 & 7.13 & $(19.95,31.68)$ \\
\hline P-value & & & \\
\hline
\end{tabular}

\subsection{Soil organic carbon}

The SOC density ranged from 74.40 to $162.12 \mathrm{t} \mathrm{C} \mathrm{ha}^{-1}$ in the $0-40 \mathrm{~cm}$ layer for the natural forest (Table 4). Under E. globulus plantation it ranged from 89.47 to $111.92 \mathrm{t} \mathrm{C} \mathrm{ha}^{-1}$ in top the $0-40 \mathrm{~cm}$ layer. SOC densities were generally higher in the $C$. lusitanica plantation than in the natural forest and E. globulus in 0-40 cm layer. It ranged from 103.94 to $165.91 \mathrm{t} \mathrm{C} \mathrm{ha}^{-1}$ in the $0-40 \mathrm{~cm}$ layers respectively under $C$. lusitanica. The differences were positively significant only in the case of the C. lusitanica and not significant in the case of E. globulus plantations. But in the second layer $(20-40 \mathrm{~cm})$, only E. globulus was negatively significant at (p-value $=0.005)$. 
Table 4: Soil organic carbon of natural forest and two different species plantations in Setema forest Southwestern Ethiopia

\begin{tabular}{llll}
\hline Depths & $(0-20 \mathrm{~cm})$ & $(20-40 \mathrm{~cm})$ & $(0-40 \mathrm{~cm})$ \\
\hline & & & \\
Natural Forest & $62.96 \pm 15.56$ & $42.76 \pm 10.94$ & $105.73 \pm 24.11$ \\
E. globulus & $63.26 \pm 6.07$ & $35.34 \pm 5.10$ & $98.60 \pm 7.01$ \\
C. lusitanica & $78.55 \pm 6.16$ & $54.41 \pm 17.75$ & $132.96 \pm 17.58$ \\
\hline p-value & 0.003 & 0.007 & 0.000 \\
\hline
\end{tabular}

\subsection{Ecosystem carbon stocks}

Total C (AGBC + BGBC + SOC) in the natural forest, Eucalyptus globulus, and Cupressus lusitanica were 370.03, 267.06, and $258.04 \mathrm{C}$ ton $\mathrm{ha}^{-1}$ respectively. There were significantly higher total $\mathrm{C}$ in the natural forest than the plantations. E. globulus plantation had the second largest total C stock (table, 5), because of higher biomass than C. lusitanica and though it is not statistically significantly higher than that the total $\mathrm{C}$ of the C. lusitanica. Table 5: Average $\mathrm{C}$ storage potential in the different pools by major forest stands in study area.

\begin{tabular}{|c|c|c|c|c|}
\hline \multicolumn{5}{|c|}{ C storage capacity ( $\mathrm{t} / \mathrm{ha}$ ) in different pools } \\
\hline Forest stands & $\mathrm{AGC}$ & BGC & SOC & Total \\
\hline Natural forest & 210.8 & 53.50 & 105.73 & 370.03 \\
\hline E. globulus & 133.7 & 34.76 & 98.60 & 267.06 \\
\hline C. lusitanica & 99.8 & 25.81 & 132.96 & 258.57 \\
\hline p-value & 0.000 & 0.000 & 0.000 & 0.000 \\
\hline
\end{tabular}

AGC: aboveground carbon; BGC: belowground carbon; and SOC: soil organic carbon.

Calculated in all forest types, the natural forest had higher biomass $\mathrm{C}$ densities than the plantations. SOC densities were generally higher in the $C$. lusitanica than in the natural forest and E. globulus.

\section{Discussion}

\subsection{Biomass $\mathrm{C}$ density}

The observed differences in $\mathrm{C}$ stocks between forests types are primarily due to the replacement of natural forest with exotics through lose of biomass carbon in forest ecosystem. As there were no such comparative studies, there is no baseline biomass or soil carbon data available against which to compare our current carbon density values of the study area. However, from local knowledge, observation, and secondary data, it is known that most of the plantations in the Setema forest are on land that had been cleared of natural forest and the plantations, with the same management, have been protected and largely remained unutilized. The total biomass carbon in Setema natural forest (264.3 ton/ha) was lower than values reported by Dibaba et al (2019) which was 288.82.t/ha for Carbon stock of Gerba-Dima moist Afromontane forest, South-western Ethiopia. According to the study by Mohammed Abaoli and Bekele Lemma (2014) on the Belete-gera forest, moist montane forest in South Western Ethiopia, a mean biomass $\mathrm{C}$ densities of $135.00 \pm 36.63 \mathrm{Mg} \mathrm{C} \mathrm{ha}^{-1}$ was reported for the natural forest. The result of this study natural forest biomass carbon stocks in line with Gera Afromontane Rain forest biomass carbon stock (260.81 t/ha) (Nesru Hassen, 2015).

Table: 6 Comparison of biomass carbon stocks ( $\mathrm{t} / \mathrm{ha}$ ) of the present result of natural forest with other studies

\begin{tabular}{lccc}
\hline Study Place & AGBC & BGBC & TBC \\
\hline Setema natural forest (this study) & 210.8 & 53.50 & 264.3 \\
Arba Minch Ground Water Forest (Belay Melese et al., 2014) & 414.70 & 83.48 & 498.18 \\
Egdu Forest (Adugna Feyissa et al., 2013) & 278.08 & 55.62 & 333.7 \\
Menagasha Suba State Forest (Mesfin Sahile, 2011) & 133.00 & 26.99 & 159.99 \\
Ades forest (Kassahun et al., 2015) & 259.165 & 52.19 & 311.35 \\
Moist Afromontane (MEFCC, 2018) & & $96-243$ \\
Natural high forest carbon stock of Ethiopia (Temam, 2010). & & 200 \\
\hline
\end{tabular}

$\mathrm{AGBC}=$ Aboveground Biomass Carbon; $\mathrm{BGBC}=$ Belowground Biomass Carbon; $\mathrm{TBC}=$ Total Biomass Carbon.

Moreover, the variation of carbon stock in biomass depends on many factors such as the stand structure and composition, topography, altitude, disturbance, forest fire and fuelwood collection, microclimate. The difference in biomass $\mathrm{C}$ densities amongst these cited studies may partly be related to the use of different allometric biomass functions, wood density values used, tree size included in the calculations, and sampling methods and designs (Mulugeta Zewdie et al., 2009).

The biomass $\mathrm{C}$ density of natural forest was significantly higher than that of the C. lusitanica and E. globulus 
plantations. The result indicated that average aboveground $\mathrm{C}$ in the tree plantations was better in Eucalyptus species (133.7 t/ha) than in C. lusitanica (99.8 t/ha). According to Birhanu Iticha (2017), in Chato Afromontane Forest, Western Ethiopia biomass carbon for E.globulus and C. lusitanica was reported to be 254.29, $223.37 \mathrm{t} / \mathrm{ha}$ respectively. Patula and Oeba, (2016) also estimated of aboveground and belowground carbon sequestration of Eucalyptus and C. lusitanica plantation species in Kenya as 247.9 and 98.4 t/ha respectively.

The $\mathrm{C}$ densities of the C. lusitanica in Setema forests were lower than the Eucalyptus plantation, as indicated by the lower dbh and basal area values (Table1). The biomass $\mathrm{C}$ density of the Eucalyptus plantations was not similar to that of the natural forest, but this can be attributed to a relatively high proportion of $C$. lusitanica plantation. The aboveground biomass $\mathrm{C}$ densities of the E. globulus plantations were higher next to those of the natural forest (table 2).

The establishment of plantations on either the disturbed or previously forest land had reduced the tree and total biomass carbon compared to the reference adjacent natural forest. This may be due to the difference in the species composition and higher age of trees and higher average DBH under the natural forest relative to the younger age and pure stands of plantations. Diversity of trees and the stand structural variables such as basal area and percentage of large trees (higher DBH range) were found to explain a high variability of the estimated biomass and carbon density of natural forest than plantations (Mensah et al., 2016).

The significant difference in the amount of aboveground and belowground carbon sequestered between species may be explained by the nature of tree species, age, and site conditions such as soil. E. globulus is generally known to grow fast and accumulate more biomass than $C$. lusitanica resulting in a high amount of carbon sequestration within the same period. Eucalyptus is also known to be self-pruning thus demanding less silvicultural management as compared $C$. lusitanica which requires such operations at a specific time of growth to improve on their stem quality and total biomass. Delays of such operational management are more likely to affect the diameter growth, which is a key parameter on tree volume that has a direct relationship on the estimation of the total biomass from the stem density (Patula and Oeba, 2016).

\subsection{SOC density}

The results showed that the amount of $\mathrm{C}$ stored in the top $20 \mathrm{~cm}$ soil layer has the order: C. lusitanica $>$ E. globulus $>$ natural forest. The amount of $C$ stored in the second $(20-40 \mathrm{~cm})$ soil layer and total depth $(0-40 \mathrm{~cm})$ has the order: C. lusitanica $>$ natural forest $>E$. globulus. Compared in terms of the soil organic carbon subject to natural forest, E. globulus and C. lusitanica plantations stored more organic carbon. This means that soil organic carbon under C. lusitanica was higher than the soil organic carbon under the adjacent natural forest.

Table: 7 Comparison of soil organic carbon $(\mathrm{t} / \mathrm{ha})$ of the present result of different forest stand with other studies

\begin{tabular}{ccccc}
\hline & \multicolumn{3}{c}{ Forest categories } & Study Place (reference) \\
\cline { 2 - 4 } & N. forest & E. globulus & C. lusitanica & \\
\hline SOC t/ha & 105.73 & 98.60 & 132.96 & Setema forest (this study) \\
SOC kg/ha & 93 & 87 & 86.1 & Munessa Forest, (Abate, 2004), \\
SOC t/ha & 71.04 & 41.70 & 53.16 & Chato forest(Birhanu Iticha, 2017) \\
SOC t/ha & 305 & 209 & 252 & Kenya (Omoro et al (2013) \\
\hline
\end{tabular}

In this study with respect to the total SOC stock under the natural forest and two exotic species plantation in the $0-20 \mathrm{~cm}$ soil depth, the natural forest had a lower SOC compared to the C. lusitanica plantations. This is due to might be the low input of fresh litter as is indicated by the low $\mathrm{C}$ low amount of $\mathrm{C}$ found under the natural forest in the $0-20 \mathrm{~cm}$ soil depth, compared to plantations.

According to the study by Anatoli (2012) conducted at Munessa-Shashemene natural forest, the SOC of the natural forest in the 10-20 layer $\mathrm{cm}$ remained low over the decade and a possible explanation for this might be the low input of fresh carbon as is indicated by the low $\mathrm{C}$ in the $0-20 \mathrm{~cm}$ layer under natural forest.

Result indicated that the SOC under natural forest and plantations were higher in the top 0- to 20-cm soil depth and decreased in the second layer $(20-40 \mathrm{~cm})$. It is conformity with those reported for South Central Ethiopia (Lemenih et al., 2005) and Demessie et al., (2011) reported for Gambo district Southern Ethiopia. They reported that the larger portion of $\mathrm{C}$ was confined to the 0 - to 10- and 10- to 20-cm depths. Similarly, as described by Russell et al (2007) the larger portion of SOC was accumulated in the upper 0- to 15-cm soil layer following the planting of trees in an abandoned pasture at La Selva Biological Station, Costa Rica.

The higher SOC in the upper layers relative to the lower depth is attributed to the continuous supply of litter, reduced rate of disturbance little erosion impact and lower temperature under the canopy of the closed forest that may reduce decomposition favoring an increase in residence time of soil organic matter (Erskine et al., 2002).

In this study, at its maturity age (40 years old), $C$. lusitanica was found to store significantly higher amount of C than E. globulus of equal age (Setema district OFWE Office, 2018) and slightly higher than a natural forest in top $40 \mathrm{~cm}$ soil layer. The study showed that converting of natural with C. lusitanica and E. globulus plantations net accumulation of SOC depends on plantation species. At 0-40 cm soil depth C. lusitanica and E. globulus plantations had $25.75 \%$ higher and $6.76 \%$ lower SOC storage respectively compared to adjacent natural forest. 
Accordingly, SOC under plantations was higher (10.05 t/ha) $9.5 \%$ in the top $0-40 \mathrm{~cm}$ soil depth. Might be because of plantations were established on previously natural forest not loosed soil organic carbon, and might be restored in 40 years, even if it was loosed.

According to Wainkwa Chia et al (2017) study conducted at Wondo Genet, Southern Ethiopia, restoration of SOC to the level of original natural forest through afforestation in agricultural lands may be a rather complicated matter and degree of restoration of SOC following afforestation may depend on the integration of various factors including: vegetation type of afforestation (e.g., composition and diversity), climate factors, soil properties (e.g., soil type and $\mathrm{pH}$ ), time after conversion, and the degree of soil $\mathrm{C}$ loss due to cultivation before afforestation

According to Anatoli (2012) a total SOC increased by $25 \%$ under C. lusitanica and $20 \%$ under Eucalyptus within a decade. This is also in agreement with Abate (2004) who reported greater amounts of SOC under $C$. lusitanica compared to natural forest and E. globulus. In the study conducted at Wondo Genet College of Forestry and Natural Resources, Southern Ethiopia, depending on species type, SOC can restore or even increase above the original level through plantation and it may be attributed to a greater input of organic matter including SOC than a loss of organic matter in plantation (input $>$ loss of organic matter) (Wainkwa Chia et al., 2017). The SOC content of any land use was governed by the level of biomass, species diversity, quantity of litter fall and management condition (Mulugeta et al., 2005).

The higher amount of SOC stored under C. lusitanica can be explained by the larger amount of litter biomass of C. lusitanica than Eucalyptus. What possibly could have made the difference in SOC between C.lusitanica and Eucalyptus was the larger quantity of branches and coarse root litter produced under Cupressus plantations (Abate, 2004; Lemma et al., 2007). The lower amount of litter produced under Eucalyptus plantations in combination with the slow decomposition rate resulted in a lower amount of SOC. The E. globulus site in this study is located close to the village which probably results in an intensive collection of litter for fuelwood purposes.

Generally, converting natural forest to E.globulus and C. lusitanica plantations was loosed 27.82\% (102.97 $\mathrm{t} / \mathrm{ha}$ ) and $30.12 \%(111.46 \mathrm{t} / \mathrm{ha})$ carbon stock of the ecosystem in the study area respectively. This finding has shown that forest land conversion to exotic species plantations would actually lose total $\mathrm{C}$, but it was depending on species types. The carbon stock in the natural forest was found to be significantly higher than the carbon stock in the plantation forests. It is demonstrated that ecosystem $\mathrm{C}$ pools, including those in above- and belowground biomass, were lower in plantations than in natural forests but, soil carbon was lower in natural forest. Ecosystem $\mathrm{C}$ pools discussed above were statistically different between plantations and natural forests, such differences were affected by various factors. High variabilities were observed between the two different groups in relation to these factors in this study, indicating that watchfulness is needed in predicting the differences on the basis of mean effects. Many of these factors are well known to affect ecosystem C pools (Guo and Gifford, 2002) For example, stand age of plantations and site preparation for plantation establishment might have an impact on the accumulation of aboveground biomass and litter and then affect ecosystem $\mathrm{C}$ sequestration. Additionally, improper silvicultural activities in plantations might have accelerated ecosystem C loss in plantations (Berthrong et al., 2009) Site preparation with burnt treatment, for example, increased soil $\mathrm{C}$ loss, compared with unburnt one. To avoid ecosystem degradation associated with plantations, restoration measures need to be implemented to persuade ecosystems toward their natural potentials.

\section{CONCLUSIONS AND RECOMMENDATION}

\subsection{Conclusions}

The results of this finding indicated that conversion of natural forest to plantation mainly affects the carbon stocks either in their biomass or soil organic matter. This study showed that natural forest cleared for exotic species plantation areas lose high organic carbon in biomass and it was not significant soil organic carbon within more than 40 years old E. globulus plantations. The natural forest of the Setema generally had higher biomass $\mathrm{C}$ densities than plantations of exotic species.

The average aboveground $\mathrm{C}$ in the tree plantations were more in Eucalyptus plantation (133.7 t/ha) and SOC was higher in C. lusitanica (132.96 t/ha) than natural forest and E. globulus. Generally, natural forest has better carbon stock than plantation; because the natural forest has higher biomass carbon.

The plantation of $C$. lusitanica was more suitable to sequester SOC than E. globulus plantation and natural forest. However, Eucalyptus plantations also had positive effects on SOC $(0-20 \mathrm{~cm})$ which is higher than SOC under natural forest, but statistically non-significant. It was concluded that Setema natural forests sequestered more $\mathrm{C}$ trough biomass than plantations and C. lusitanica plantation sequestered more soil C than E. globulus plantations and natural forest. In general, replacing natural forest with exotic plantation attributed to the loose of $28.16 \%$ (104.215 t/ha) C from the ecosystem. So it's better to conserve natural forest instead of replacing by plantation from the perspective of maintaining carbon stocks.

\subsection{Recommendation}

$>$ Replacing natural forest with plantation has a significant effect in reducing carbon sequestrations, 
particularly when they remove long-lived natural forest that stores more carbon than exotic species plantation.

$>$ It is important to note the growth of planted forests is increasing in the future, thus plantations should not be used to replace natural forests. There is a need for taking into account the contribution of species in total carbon sinks. These demands for more awareness of different potentials each tree species has in carbon sequestration.

$>$ The species difference in influencing on soils carbon stocks of natural forest was apparently strong.

$>$ Therefore, species selection is imperative when establishing tree plantations with the aim of restoration of degraded soils and biomass carbon. It suggests that SOC can be sequestered, restored or maintained through the plantation and through careful selection of species such as C. lusitanica for plantation establishment as the increases in SOC seen, when compared to that of the reference natural forest.

$>$ Conservation of the natural forest will have an imperative implication to the total $\mathrm{C}$ density and ensuring its viability.

\section{ACKNOWLEDGMENT}

First of all, I would like to thank MRV Projects and OFECCA, for financial support of this work. Secondly, my friends are acknowledged for their friendship and support during my enrolment especially that of Abdulkeim Jemal and my brother Abdulaziz Awol were so special to me. It would be a mistake not to mention the role of the daily workers in this study who kindly spared their time and effort during the lengthy process of data collection. My Sincere gratitude goes to my principal advisor Motuma Tolera $(\mathrm{PhD})$, for his great support and help by his professional guidance and encouragement in undertaking this study, and inducing constructive comment on my work. Finally my great thanks also goes to Hawassa University, Wondo Genet College of forestry and natural resources, for their best cooperation in material and technical support.

\section{REFERENCES}

Abate, A. 2004. Biomass and Nutrient Studies of Selected Tree Species of Natural and Plantation Forests: Implications for a Sustainable Management of the Munessa-Shashemene Forest, Ethiopia.

Alebachew, M .2012. Traditional agro-forestry practices, opportunities, threats and research need in the highlands of Oromiya, Central Ethiopia Open access, Int. Res. J. Agric. Soil Sci. 2 (5), 194-206 (ISSN: 2251-0044)

Ambachew Demessie, Bal Ram Singh \& Rattan Lal. 2011. Soil Carbon and Nitrogen Stocks Under Plantations in Gambo District, Southern Ethiopia, Journal of Sustainable Forestry, 30:6, 496-517.

Addisu, S., Kendie, G., \& Abiyu, A. 2019. Biomass and soil carbon stocks in different forest types, Northwestern Ethiopia Intl. J. River Basin Management, O(0), 1-19. https://doi.org/10.1080/15715124.2019.1593183

Baccini, N Laporte, S J Goetz, M Sun, and H Dong. 2008. A first map of tropical africa's above-ground biomass derived from satellite imagery. Environmental Research Letters, 3(4):045011,

Baldock, J, Skjemstad, J and Bolger, T. 2007. Managing the carbon cycle ${ }^{e e}$ In Garden, D., Dove, H.and Bolger, T. (eds.) Pasture systems: managing for a variable climate. Proceedings of the 22nd Annual Conference of the Grasslands Society of NSW Queanbeyan, Grassland Society of NSW, 5-9.

Baker, D.F. 2007. Reassessing carbon sinks. Science 316: 1708-1709.

Bekele, A. 2007. Useful trees and shrubs of Ethiopia: Identification, Propagation and Management for 17 Agroclimatic Zones. Technical Manual No 6. RELMA in ICRAF Project, Nairobi, Kenya. 552 pp.

Berhe, L., Assefa, G., \& Teklay, T. 2013. Models for estimation of carbon sequestered by Cupressus lusitanica plantation stands at Wondo Genet, Ethiopia. Southern Forests: a Journal of Forest Science (Vol. 75). https://doi.org/10.2989/20702620.2013.805511

Berthrong ST, Jobba'gy EG, Jackson RB. 2009. A global meta-analysis of soil exchangeable cations, pH, carbon and nitrogen with afforestation. Ecology Applications

Bishma PS, Shiva SP, Ajay P, Eak R, Sanjeeb B, et al. 2010. Forest carbon stock measurement: Guidelines for measuring carbon stock in community managed forest. Funded by Norwegian

Brown, S. 2002. Measuring carbon in forests: current status and future challenges. Environmental Pollution 116 : 363-372.

Cairns MA, Brown S, Helmer EH, Baumgardner GA. 1997. Root biomass allocation in the world's upland forests. Oecologia 111: 1-11.

Carle, J., Vuorinen, P., and Del Lungo, A. 2002. Status and trends in global forests plantation development. Forest Products Journal, 52, 12-23.

Chave J, Réjou-Méchain M, Búrquez A, Chidumayo E, Colgan MS. 2014. Improved allometric models to estimate the aboveground biomass of tropical trees. Glob Change Biol 20: 3177-3190.

Chen, C.R., Xu, Z.H., \& Mathers, N.J. 2004. Soil carbon pools in adjacent natural and plantation forests of subtropical australia. Soil Science Society of America Journal, 68, 282-291.

Chidumayo, E., Okali, D., Kowero, G., Lrwanou, M. (eds.). 2011. Climate change in African forest and wildlife 
resources. African Forest Forum, Nairobi, Kenya

Climate Change Science Program (CSP). 2007. The first state of the carbon cycle report (SOCCR)-The North American carbon budget and implications for the global carbon cycle.

Davis, M.R., and Condron, L.M. (2002). Impacts of grassland afforestation on soil carbon in New Zealand: A review of paired site studies. Aust. J. Soil Res, 40, 675-690.

Dechassa, L. 2000. Field Assessment Report: Jimma Zone of Oromia Region. Jimma, Ethiopia : 2-11.

De Vletter, J. 1991. Forest genetic resources of Ethiopia. - In J. M. M. Engles, et al., eds. Plant genetic resources of Ethiopia. Cambridge University Press, UK, 83-99,

Erskine,W. D., Mahmoudzadeh, A., \& Myers, C. 2002. Land use effects on sediment yields and soil loss rates in small basins of Triassic sandstone near Sydney, NSW, and Australia. Catena, 49, 271-287.

Ethiopia's Forest Reference Level (FREL). 2016. Ethiopia's Forest Reference Level Submission to the UNFCCC. Ethiopia's Forest Reference Level (FREL). 2017. Ethiopia's Forest Reference Level Submission to the UNFCCC.

FAO .2001. Soil Carbon Sequestration for Improved Land Management, World Soil Resources Reports 96, Food and Agriculture Organization (FAO) Rome, Italy

FAO. 2003. State of the World forest: The situation and developments in the forest sector, part one. FAO, Rome.

FAO (Food and Agriculture Organization) . 2005. The importance of soil organic matter: key to drought - resistant soil and sustained food production, Soils Bulletin 80 , FAO, Rome

(FAO) Food and Agriculture Organization of the United Nations. 2012a. Planted Forests. Retrieved from http://www.fao.org/forestry/plantedforests/en/.

FAO, .2015. Assessment of forests and carbon stocks, 1990-2015 Reduced overall emissions, but increased degradation. Rome, Italy: Food and Agriculture Organization.

FAO. 2010. Global forest resources assessment, country report Ethiopia. Rome: FAO

Fu, B.J., Liu, S.I., Ma, K.M., Zhu, Y.G. 2004. Relationships between soil characteristics, topography and plant diversity in a heterogeneous deciduous broad-leaved forest near Beijing, China. Plant a nd Soil 261: 47-54.

Gatzweiler, F.W. 2007. Deforestation of Ethiopian afromontane rainforest, reasons for concern. Bonn, ZEF policy no.7. Center for Development Research, Bonn, Germany, p. 8.

Gebrekidan Teklu .2003. Expanse of Plantation Forest in Ethiopia (An outcome of more than half a century's effort). MoA, NRM and RD, Addis Ababa.

Geider, J.R., Delucia, H.E., Falkowsk, G.P., Finzi, C.A., Grime, P.J., Grace, J., Kana, M.T. and Roche. 2001. Primary productivity of planet earth: biological determinants and physical constraints in terrestrial and aquatic habitats. Global Change Biology 7:849-882.

Gibbs, H.K., Brown, S., Niles, J.O., Foley, J.A . 2007. Monitoring and estimating tropical forest carbon stocks: making REDD a reality. Environmental Research Letters 2: 045023

Girma, D. 1998. Non-wood products in Ethiopia. -. EC-FAO partnership programme, Addis Ababa.

Glenday J. 2006. Carbon storage and emissions offset potential in an East African tropical rain- forest. Forest Ecology and Management 235: 72-83

Guo LB, Gifford RM. 2002. Soil carbon stocks and land use change: a meta- analysis. Global Change Biology 8: 345-360.

Grove, T.S., O’Connell, A.M., Mendham, D.S., Barrow, N.J. and Rance, S.J. 2001. Sustaining the Productivity of Tree Crops on Agricultural Land in South-western Australia, Publication No.10/09. Rural Industries Research and Development Corporation (RIRDC), Canberra.

Hairiah, K., Dewi, S., Agus, F., Velarde, S., Ekadinata, A., Rahayu, S. and Van Noordwijk, M. 2011. Measuring carbon stocks across land use systems: A Manual. Bogor, Indonesia. World Agroforestry Centre (ICRAF), SEA Regional Office, 154 pages

Holly, K., Gibbs Brown, S., Niles, J. O. and Foley, J. A. 2007. Tropical Deforestation an Carbon Emissions: Introduction to Special Issue. Environmental Resource Letter, 2 045021, p2.

Houghton, R. A. 2005. Aboveground Forest Biomass and the Global Carbon Balance. Global Change Biology, 11: 945-958

Houghton, R.A., Lawrence, K.T., Hackler, J.L., Brown, S. 2001. The spatial distribution of forest biomass in the Brazilian Amazon: a comparison of estimates. Global Change Biology 7: 731- 746

IPCC (Intergovermental Panel on Climate Change). 2000. Land Use, Land-Use Change and Forestry. Cambridge: Cambridge Univ.Press (ISBN: 92-9169-114-3).

IPCC. 2006. IPCC Guidelines for National Greenhouse Gas Inventories. Eds. S Eggelston, L Buendia, K Miwa, T Ngara and K Tanabe. The Institute for Global Environmental Strategies (IGES), Hayama, Japan.

IPCC. 2007. The Scientific Basis: IPCC fourth assessment report, Working Group I.

IPCC (Intergovernmental Panel on Climate Change). 2013. The Physical Science Basis. Contribution of Working Group I to the Fifth Assessment Report of the Intergovernmental Panel on Climate Change [Stocker, T.F., D. Qin, G-K. Plattner, M. Tignor, S.K. Allen, J. Boschung, A. Nauels, Y. Xia, V. Bex and P.M. Midgley (eds.)]. Cambridge University Press, Cambridge, United Kingdom and New York, NY, USA, 1535 pp. doi: 


\section{$10.1017 / \mathrm{CBO} 9781107415324$}

Iticha, B. 2017. Ecosystem Carbon Storage and Partitioning in Chato Afromontane Forest: Its Climate Change Mitigation and Economic Potential. International Journal of Environment, Agriculture and Biotechnology, 2(4), 1785-1794. https://doi.org/10.22161/ijeab/2.4.41

Jackson. 1996 .A global analysis of root distributions for terrestrial biomes

Jaramillo, V.J., Kauffman, J.B., RenteíaRodríguez, L., Cummings, D.L., Ellingson, L.J. 2003. Biomass, carbon nitrogen pools in Mexican tropical dry forest landscapes. Ecosystem 6, 609-629. http://dx.doi.org/10.1007/s10021-002-0195-4

Jobbágy, E.G. \& Jackson, R.B. 2001. The distribution of soil nutrients with depth: Global patterns and the imprint of plants. Biogeochemistry 53, 51-77.

Kassahun, K., Soromessa, T., \& Belliethathan, S. 2015. Forest Carbon Stock in Woody Plants of Ades Forest , Western Hararghe Zone of Ethiopia and its Variation along Environmental Factors : Implication for Climate Change Mitigation, 5(21), 96-109.

Lal, R. 2005. Forest soils and carbon sequestration. Forest Ecology and Management 220 (1-3): 242-258

Lal, R. 2004a. Soil carbon sequestration impacts on global change and food security. Science 304: 1623-1627.

Lemenih, M., \& Itanna, F. 2004. Soil carbon stocks and turnovers in various vegetation types and arable lands along an elevation gradient in southern Ethiopia, 123, 177-188. https://doi.org/10.1016/j.geoderma.2004.02.004

Lemenih, M., Olsson, M., \& Karltun, E. 2004. Comparison of soil attributes under Cupressus lusitanica and Eucalyptus saligna established on abandoned farmlands with continuously cropped farmlands and natural forest in Ethiopia, 195, 57-67. https://doi.org/10.1016/j.foreco.2004.02.055

Lemma B., Kelja D.B., Nilsson I., Olsson M. 2006. Soil carbon sequestration under exotic tree species in southwestern highlands of Ethiopia. Geoderma 136(3-4): 886-898.

Lemma, B., Kleja, D., B., Olsson, M., and Nilsson, I. 2007. Factors controlling soil organic carbon sequestration under exotic tree plantations: A case study using the CO2 Fix model in

Malhi, Y., Meir, P., and Brown, S. 2002. Forests, carbon and global climate. Philos. Trans. R. Soc. Lond. A 360: 1567-1591.

Matamala, R., Gonzàlez- Meler, M.A., Jastrow, J.D., Norby, R.J., and Schlesinger, W.H. 2003. Impacts of fine root turnover on forest NPP and soil carbon sequestration potential. Science 302: 1385-1387.

McLean EO. 1982. Soil pH and lime requirement. In: Miller AL, Keeney RD (Eds) Methods of soil analysis. Part 2 - Chemical and microbiological properties. Agronomy 9: 199-223.

Mendham, D.S., O'Connell, A.M. and Grove, T.S. 2002. Change in soil carbon after land clearing or afforestation in highly weathered lateritic and sandy soils of south-western Australia. Agri. Eco. Env. 95:143-156.

Mensah, S., Veldtman, R., Toit, B., Kakaï, R. G., \& Seifert, T. 2016. Aboveground Biomass and Carbon in a South African Mistbelt Forest and the Relationships with Tree Species Diversity and Forest Structures. https://doi.org/10.3390/f7040079

Ministry of Environment, Forest and Climate Change (MEFCC) forest, N. and Development, S. 2018 'National Forest Sector Development Program, Addis Abeba, Ethiopia

Moges, Y., Eshetu, Z., and Nune, S. 2010 'Ethiopian Forest Resources: Current Status and Future Management Options In View of Access to Carbon Finances. Ethiopian Climate Research and Networking and the United Nations Development Programme (UNDP) Addis Ababa, Ethiopia', 56 pp. MoA. 2000. Agroecological zonations of Ethiopia, Addis Ababa, Ethiopia.

Mohammed, A., \& Bekele, L. 2014. Changes in Carbon Stocks and Sequestration Potential underNative Forest and Adjacent Land use Systems at Gera, South-Western Ethiopia, 14(10)

Mulugeta Lemenih, Bekele Lemma, Demel Teketay. 2005. Changes in soil carbon and total nitrogen following reforestation of previously cultivated land in the highlands of Ethiopia. Ethiopian Journal of Science 28(2): 99-108

Mulugeta Zewdie., Olsson, M., Vewijst, T., 2009. Above ground biomass production and allometric rela- tions of Eucalyptus globulus Labill. Coppice plantations along a chronosequence in the cen- tral Highland of Ethiopia. Biomass and Bioenergy 33(3): 421-428.

Murty D, Kirschbaum MF, Mcmurtrie R, Mcgilvray H .2002. Does con- version of forest to agricultural land change soil carbon and N? A review of the literature. Glob Chang Biol 8:105- 123. doi:10.1046/j.13541013.2001.00459.

Nair, P.K.R., Kumar, B.M., and Nair, V.D. 2009. Agroforestry as a strategy for carbon sequestration. J. Plant Nutr. Soil Sci. 172: 10-23.91

Nyssen, J., Poesen, J., Moeyersons, J., Deckers, J., Haile, M., Lang, A. 2004. Human impact on the environment in the Ethiopian and Eritrean highlands, a state of the art. Earth Sci. Rev. 64- (34), 273-320

Olsson, M. 2001. Do trees improve the soil? Swedish University of Agricultural Sciences. Currents 25/26: 31-34.

Omoro, L. M. A., Starr, M., \& Pellikka, P. K. E. 2013. Tree biomass and soil carbon stocks in indigenous forests 
in comparison to plantations of exotic species in the Taita Hills of Kenya, 47(2), 1-18.

Patula, P., \& Oeba, V. O. 2016. Estimation Of Aboveground And Belowground Carbon Sequestration Of Cupressus And Eucalyptus Saligna Plantation Species In Kenya, 3(6), 1-15.

Pearson, T., \& Brown, S. 2005. Sourcebook for Land Use, Land-Use Change and Forestry Projects.

Picard N, Saint-Andre L, Henry M. 2012. Manual for building tree volume and biomass allometric equations: from field measurement to prediction. Food and Agricultural Organization of the United Nations, Rome, and Centre de Coopération Internationale en Recherche Agronomique pour le Développement, Montpellier 215

Poultouchidou, A. 2012. Effects of forest plantations on soil carbon sequestration and farmers ' livelihoods - A case study in Ethiopia.

Rautiainen, A., Saikku, L., Kauppi, P.E. 2010. Carbon gains and recovery from degradation of forest biomass in European Union during 1990-2005. Forest Ecology and Management. 259, 1232-1238

Ravindranath N, Ostwald M . 2008. Methods for estimating above-ground biomass, Carbon Inventory Methods Handbook for Greenhouse Gas Inventory, Carbon Mitigation and Roundwood Production Projects., pp 113147

Rees,R.M., Bingham, I., Baddeley, J., and Watson, C.A. 2005.The role of plants and land management in sequestering soil carbon in temperate arable and grassland ecosystems. Geoderma 128: 130-154.

Report, S. I. 2010. A Method for Assessing Carbon Stocks, Carbon Sequestration, and Greenhouse-Gas Fluxes in Ecosystems of the United States Under Present Conditions and Future Scenarios Scientific Investigations Report $2010-5233$

Rooney, D. 2013. Sustainable soil management, Apple Academic Press, INC., 3333 Mistwell Crescent, Oakville, ON161,Canada. Pp. 52.

Roshetko, J.M., Delaney, M., Hairiah, K., and Purnomosidhi, P. 2002. Carbon stocks in Indonesian homegarden systems. American Journal of Alternative Agriculture 17(2): 1-11.

Ruiz-peinado, R., Bravo-oviedo, A., López-senespleda, E., Bravo, F., \& Río, M. 2017. Forest management and carbon sequestration in the Mediterranean region: A review, 26(2), 1-25.

Russell, A. E., Raich, J. W., Valverde-Barrantes, O. J., \& Fisher, R. F. 2007. Tree species effects on soil properties in experimental plantations in tropical moist forest. Soil Science Society ofAmerica Journal, 71, 1389.

Sasaki, N., Kim, S. 2009. Biomass carbon sinks in Japanese forests: 1966-2012. Forestry..

Sigua GC, Coleman SW, Albano J . 2009. Beef cattle pasture to wetland reconversion: impact on soil organic carbon and phosphorus dynam- ics. Ecol Eng 35:1231-1236. doi:10.1016/ j.ecoleng.2009.05.00 4

Silver, W.L., Ostertag, R., Lugo, A.E. 2000. The potential for carbon sequestration through reforestation ofabandoned tropical agricultural and pasture lands. Soc. Ecol. Restor. 8, 394-407

Smith, J., Mulongoy, K., Persson, R. and Sayer, J. 2000. Harnessing carbon markets for tropical forest conservation: Towards a more realistic assessment. Environmental Conservation 27 (3): 300-311. Smith, S. V., Renwick, W. H., Buddemeier, R. W., and Crossland, C. J. 2001. Budgets of soil erosion and deposition for sediments and sedimentary organic carbon across the conterminous United States. Global Biogeochemical Cycles 15: 697-707.

Smith J.E., and Heath L.S. (2002). A model of forest floor carbon mass for United States forest types. General Technical Report, USDA Forest Service, Northeastern Research Station, Newtown Square, PA. In press.

Solomon, D., F. Fritzsche, M.Tekalign, J. Lehmann, and W. Zech. 2002. Soil organic matter composition in the subhumid Ethiopian highlands as influenced by deforestation and agricultural management 1415. Soil Science Society of America Journal 66:68-82

Stern Review. 2007. Cambridge: Cambridge University Press,. 712p.

Stickler, C.M., Nepstad, D.C., Coe, M.T., McGrath, D.G., Rodrigues, H.O., Walker, W.S., Soares-Filho, B.S., and Davidson, E.A. 2009. The potential ecological costs and cobenefits of REDD: A critical review and case study from the Amazon region. Global Change Biology, 15, 2803.

Strand, A.E., Pritchard, S.G., McCormack, M.L., Davis, M.A., and Oren, R. 2008. Irreconcilable differences: Fineroot life spans and soil carbon persistence. Science 319: 456-458

Streck, C., and Scholz, S.M. 2006. The role of forests in global climate change: Whence we come and where we go. International Affairs 82: 861-879.

Takimoto, A., Ramachandran Nair, P.K., and D. Nair, V. 2008. Carbon stock and sequestration potential of traditional and improved agroforestry systems in the West African Sahel," Agriculture, Ecosystems and Environment 125: 159-166.

Teketay, D. 2001. Deforestation, wood famine and environmental degradation in Ethiopia's highland ecosystems. Urgent need for action. Northeast. Afr. Stud. 8 (1), 53-76

Tesfaye Debela. 2017. Species Specific Allometric Equations for Biomass Estimation of Three Selected Trees Species in Egdu Forest of OromiaNational Regional State Species Specific Allometric Equations for Biomass Estimation of Three Selected Trees Species in Egdu Forest of Oromia National Regional State. M.Sc Thesis. 
Addis Ababa University, Ethiopia. 39p.

http://localhost:80/xmlui/handle/123456789/7424

Thomas, E., Harold,E., and Burkhart. 2015. Forest meansuration: Fifth Edition polytechnic institution of America. chapter three $34 \mathrm{pp}$.

UNEP. 2002. African Environment Outlook: Past, Present and Future Perspectives. United Nations Environment Programme, Nairobi (http://www.grida.no/aeo/).

Wainkwa Chia, R., Kim, D. G., and Yimer, F. 2017. Can afforestation with Cupressus lusitanica restore soil C and $\mathrm{N}$ stocks depleted by crop cultivation to levels observed under native systems? Agriculture, Ecosystems and Environment, 242(November 2016), 67-75. https://doi.org/10.1016/j.agee.2017.03.023

Walkley, A. and Black, I.A. 1934 . An examination of the Degtjareff method for determining soil organic matter and a proposed modification of the chromic acid titration method," Soil Sci. 37: 29-38.

Watson, R.T., Noble, I.R., Bolin, B., Ravindranath, N.H., Verardo, D.J., Dokken, D.J. 2000. Land Use, Land-Use Change, and Forestry. Intergovernmental Panel on Climate Change (IPCC), Special report. Cambridge University Press, UK. 375 pp.

WBISPP. 2005. Wood biomass inventory strategic planning project. A national strategy plan for the biomass sector. Technical document no. 2. Ministry of Agriculture, Addis Ababa, Ethiopia

Wolde, B. M., Kelbessa, E., \& Soromessa, T. 2014. Original Research Forest Carbon Stocks in Woody Plants of Arba Minch Ground Water Forest, 7522(June), 141-147

YamaguchiH,HiraseT,Koizumi C. 1963. Survey and pop- ulation studies of beetles in the wind-swept areas in Hokkai- do. (III) Beetle attacks on standing trees during the epidemic period, 1956 to 1958. Bull. Gov. For. Exp. Stn. (Tokyo), 151, 75-135.

Yirdaw, E. 2002. Restoration of native woody-species diversity, using plantation species as foster trees, in the degraded highlands of Ethiopia. Ph.D. thesis-University of Helsinki, Helsinki.. 